University of New Hampshire

University of New Hampshire Scholars' Repository

$5-1976$

\title{
Distribution of carbonate in surface sediments of the Pacific Ocean
}

\author{
W. H. Berger \\ University of California - Davis \\ Charles Adelseck \\ Scripps Institution of Oceanography \\ Larry A. Mayer \\ University of New Hampshire, larry.mayer@unh.edu
}

Follow this and additional works at: https://scholars.unh.edu/ccom_affil

Part of the Oceanography and Atmospheric Sciences and Meteorology Commons, and the Sedimentology Commons

\section{Recommended Citation}

Berger, W. H., Adelseck, C. G., and Mayer, L.A., 1976. Distribution of carbonate in surface sediments of the Pacific Ocean: Journal of Geophysical Research, vol. 81, no. 15, pp. 2617-2627. doi:10.1029/ JC081i015p02617

This Article is brought to you for free and open access by the Center for Coastal and Ocean Mapping at University of New Hampshire Scholars' Repository. It has been accepted for inclusion in Affiliate Scholarship by an authorized administrator of University of New Hampshire Scholars' Repository. For more information, please contact Scholarly.Communication@unh.edu. 


\title{
Distribution of Carbonate in Surface Sediments of the Pacific Ocean
}

\author{
W. H. Berger, C. G. Adelseck, Jr., and L. A. Mayer \\ Scripps Institution of Oceanography, University of California, La Jolla, California \\ 92037
}

\begin{abstract}
The distribution of carbonate on the floor of the Pacific has been remapped on the basis of 1313 points from 80 references stored in the World Ocean Sediment Data Bank of Scripps Institution of Oceanography. Percent distribution maps and carbonate versus depth diagrams generally agree with previously published information and reflect the major controlling factors of carbonate sedimentation (depth, hydrography, fertility, and sedimentary processes). While carbonate distributions are of limited use in attempting to construct dissolution profiles, major trends are identifiable. In particular, the degree of lowering of the equatorial calcite compensation depth (CCD) together with an estimate of the differences in supply rates between the equator and the subtropical gyre can be used to estimate dissolution rate increase below the lysocline. There is considerable variation in the sharpness of the 'CCD transition,' a concept defined here. This variation is thought to reflect both geographic differences in dissolution rate gradients and redeposition processes (carbonate, deep-sea sediments, calcite, and compensation depth).
\end{abstract}

\section{INTRODUCTION}

The distribution of calcium carbonate percentages in surficial sediments of the ocean floor is one aspect of the $\mathrm{CO}_{2}$ cycle, a major geochemical cycle on the surface of the planet, having first-order implications for the geology, chemistry, and micropaleontology of the oceans. Distributional patterns have been discussed since Murray [Murray and Renard, 1891, p. 215] discovered a more or less regular decrease of percentages from high values in the shallower regions of the ocean floor to very low values at abyssal depths (in the Pacific) [Revelle, 1944; Bramlette, 1961; Lisitzin and Petelin, 1967; Smith et al., 1968; Lisitzin, 1970, 1971, 1972, 1974]. Complementing the adjoining papers on Atlantic and Indian ocean patterns, we provide yet another version of such mapping for the Pacific Ocean.

Such distributional maps have many uses in conjunction with other types of data. They constitute a point of departure for investigation of virtually all aspects of the carbonate cycle in the deep ocean. However, it should be noted at the outset that by themselves they are of limited value in understanding the carbonate cycle. The parameters needed for such insight include overall input and rates of production, dissolution, and accumulation of carbonate. These parameters and their exact relationships to the observed carbonate percentages are poorly known, although there is no lack of discussion on the subject [Arrhenius, 1952; Revelle and Fairbridge, 1957; Olausson, 1960, 1965, 1967, 1971; Hoshino and Higano, 1961; Lyakhin, 1968; Heath, 1969; Li et al., 1969; Berger, 1970a, $b, 1971,1973 a, b, 1976$; Heath and Culberson, 1970; Pytkowicz, 1970; Takahashi et al., 1970; Broecker, 1971; Valencia, 1973; van Andel et al., 1975]. The problems in dealing with distributional data include the occurrence of pre-Recent carbonate sediments in many parts of the Pacific [Riedel and Funnell, 1964; Hays et al., 1969; Funnell, 1970, 1971; Broecker and Broecker, 1974; Saito et al., 1974] and the widespread evidence for redeposition

Copyright $₫ 1976$ by the American Geophysical Union.
[Parker and Berger, 1971; Moore et al., 1973]. Certain reservations therefore apply to the relevance of distributional data to the chemical state of the ocean, which recently has received considerable study in regard to the carbonate system [Pytkowicz, 1968; Chave and Suess, 1970; Berner and Wilde, 1972; Morse and Berner, 1972; Chave and Smith, 1973; Berner, 1974; Broecker, 1974; Edmond, 1974; Gieskes, 1974; Takahashi, 1975]. Direct comparisons of carbonate percentages with measured or calculated chemical parameters rest on the assumption that the factors influencing the percentages have a constant relationship to each other or can be separated (i.e., rate of supply, rate of dissolution, and rate of dilution) and that the sediment in question reflects present in situ conditions rather than those of a shallower depth (by redeposition) or of an earlier period (erosion or nondeposition). More often than not, such assumptions are poorly justified.

Some of the difficulties in the interpretation of the carbonate distribution patterns can be approached by careful attention to paleontologic data (for the Pacific) [Belyaeva and Saidova, 1965; Saidova, 1965, 1971; Bezrukov, 1969; Blair, 1965; Blackman, 1966; Kennett, 1966, 1969; Belyaeva, 1968, 1969; Herb, 1968, 1971; Berger, 1970a, 1971; Parker and Berger, 1971 and references therein; Theyer, 1971a, b; Echols and Kennett, 1973; Roth and Berger, 1975] as well as by in situ experiments on carbonate dissolution [Peterson, 1966; Berger, 1967; Ben-Yaakov and Kaplan, 1971; Ben-Yaakov et al., 1974]. Others must await more information on dissolution during settling of particles and immediately after their arrival on the sea floor [Adelseck and Berger, 1975] and on rate distributions [Broecker and Broecker, 1974; Sliter et al., 1975; Berger, 1976; van Andel et al., 1975].

Mindful of these limitations, we offer the present reconnaissance mapping with a minimum of interpretation, especially since the major distributional patterns have been known for some time [Lisitzin and Petelin, 1967; Lisitzin, 1971] and have been discussed quite recently [Berger, 1974, 1976; Berger and Winterer, 1974; Lisitzin, $1974]$. 


\section{Data Sources and Methods of Presentation}

Carbonate data include all available information, beginning with Murray and Renard [1891] and going up to Tin et $a l$. [1973]. Information from 80 references stored in the World Ocean Sediment Data Bank of Scripps Institution of Oceanography (SIO) has been used (sources available on request). Most of these are listed in the earlier compilations cited. There are 1313 data points.

The quality of the carbonate determinations varies considerably. An appreciable proportion of the points are estimates based on visual examination, as is indicated in the appropriate figure captions. While we have not eliminated these data, we have not given them much weight in interpreting the distributions. A contour map of surface sediment calcium carbonate content was compiled (Figure 1) which is in good agreement with Lisitzin and Petelin [1967]. Contours based upon inadequate data were drawn to follow topographic trends and are indicated by dashed lines. Comparison of carbonate percentage classes north and south of $10^{\circ} \mathrm{N}$ latitude (Figure 2) indicates the general scarcity of carbonate rich sediments in the North Pacific, presumably due to a predominance of sea floor at or below the calcite compensation depth (CCD). In the south the strong bimodality in the distribution reflects a rather narrow depth zone of transition between high and low carbonate content.
The Pacific Ocean was subdivided into 31 areas of unequal extent and unequal data coverage (Figure $3 a$ ). The areas are thought to be more or less homogeneous with respect to productivity, carbonate preservation, and topography, as is illustrated in Figures $3 b$ and $3 c$. Productivity patterns are based on zooplankton abundances. The calcite compensation level is based mainly on the data used in the present paper but is supplemented by information on foraminiferal distributions. Aragonite compensation depths indicate that dissolution levels at various depths are not necessarily parallel to each other.

The original subdivision was adjusted both to minimize the scatter of carbonate versus depth plots and to decrease the number of different regions (Figure 3d). The scatter diagrams of carbonate versus depth (Figures 4-7) refer to the adjusted areas in Figure 3d. Generalizations of the scatter diagrams (Figures 8-10) require operational definitions for the CCD and for the concept of the thickness of the transition zone from highly calcareous sediments to the CCD. Qualitative models of supply and dissolution rate profiles illustrate the presumed controls on the generalized carbonate-depth relationships (Figures 11 and 12).

\section{Carbonate Versus Depth}

The depth dependence of carbonate percentages, first noted by Murray, is evident in all plots with sufficient data

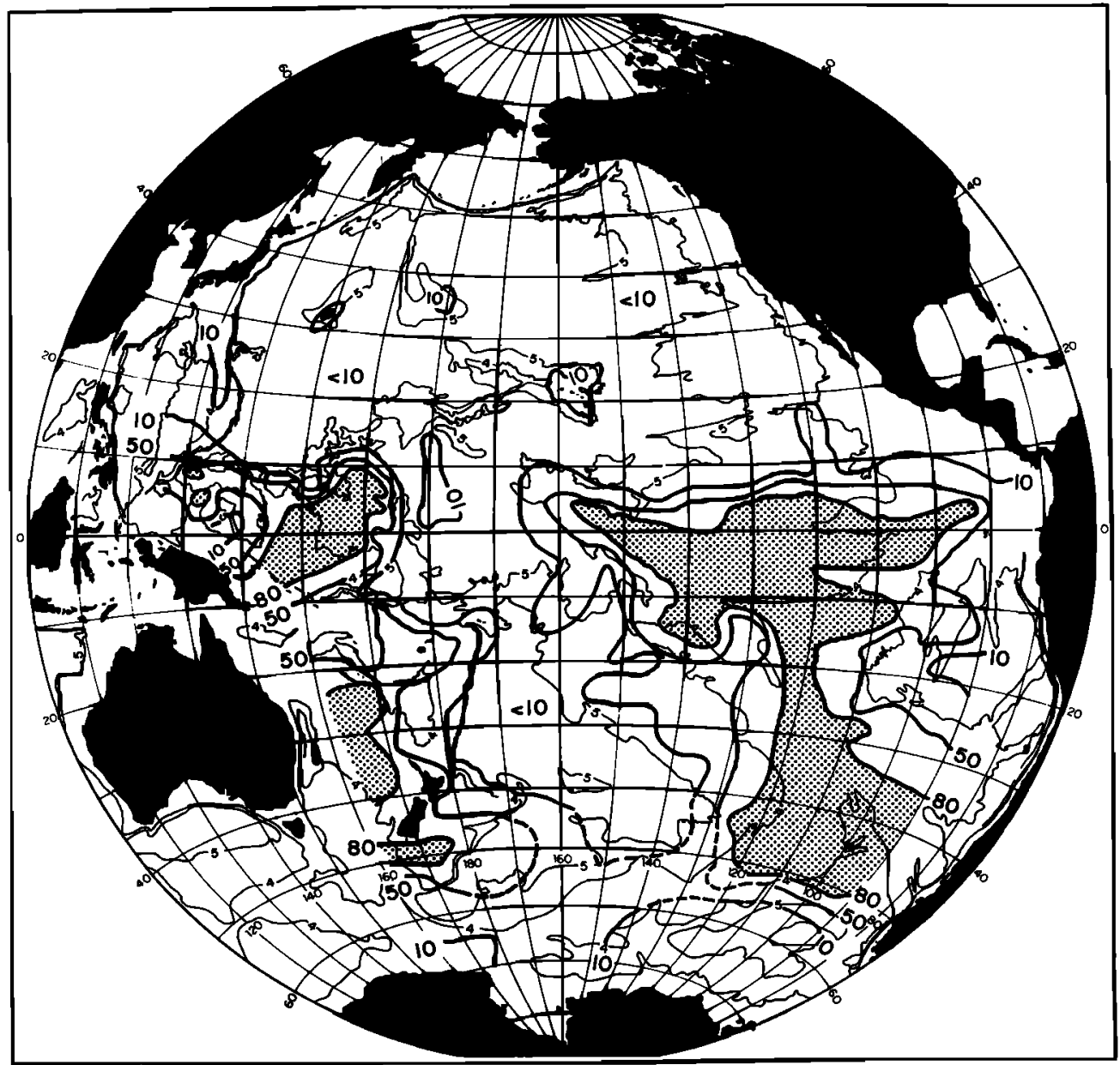

Fig. 1. A contour map of calcium carbonate percentages in Pacific surface sediments. The bathymetry is after Menard [1964]. 

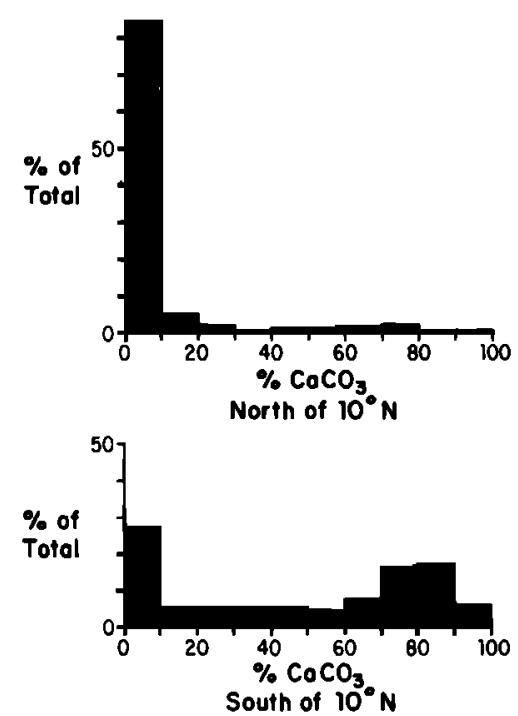

Fig. 2. The bimodal distribution of carbonate values on the Pacific sea floor. Note the low proportion of high carbonate values in the North Pacific. points. The rather sharp transition from high to low values, which led Bramlette [1961] to the concept of compensation depth, is obvious in several plots but debatable in others. Acceptance of the general validity of the CCD concept therefore would appear to depend on other information (state of preservation of microfossil assemblages and depth distribution of sedimentation rates) and on the expectation that the existence of a compensation depth follows logically from Peterson's [1966] dissolution rate profile [Berger, 1970a; Heath and Culberson, 1970]. In fact, the transition should be well defined for almost any kind of profile showing increasing dissolution rates with depth, including a linear increase [Berger, 1971]. In this view, then, the observed scatter represents disturbing influences such as redeposition processes, inhomogeneous dilution, and sampling of pre-Recent material.

\section{Generalized Curves and Calcite Compensation Depth}

We postulate from the foregoing considerations that those plots are ideal which show high carbonate values at shallow depths and a sudden transition to low values at some level (e.g., Figure 4, area 7) and that other plots are
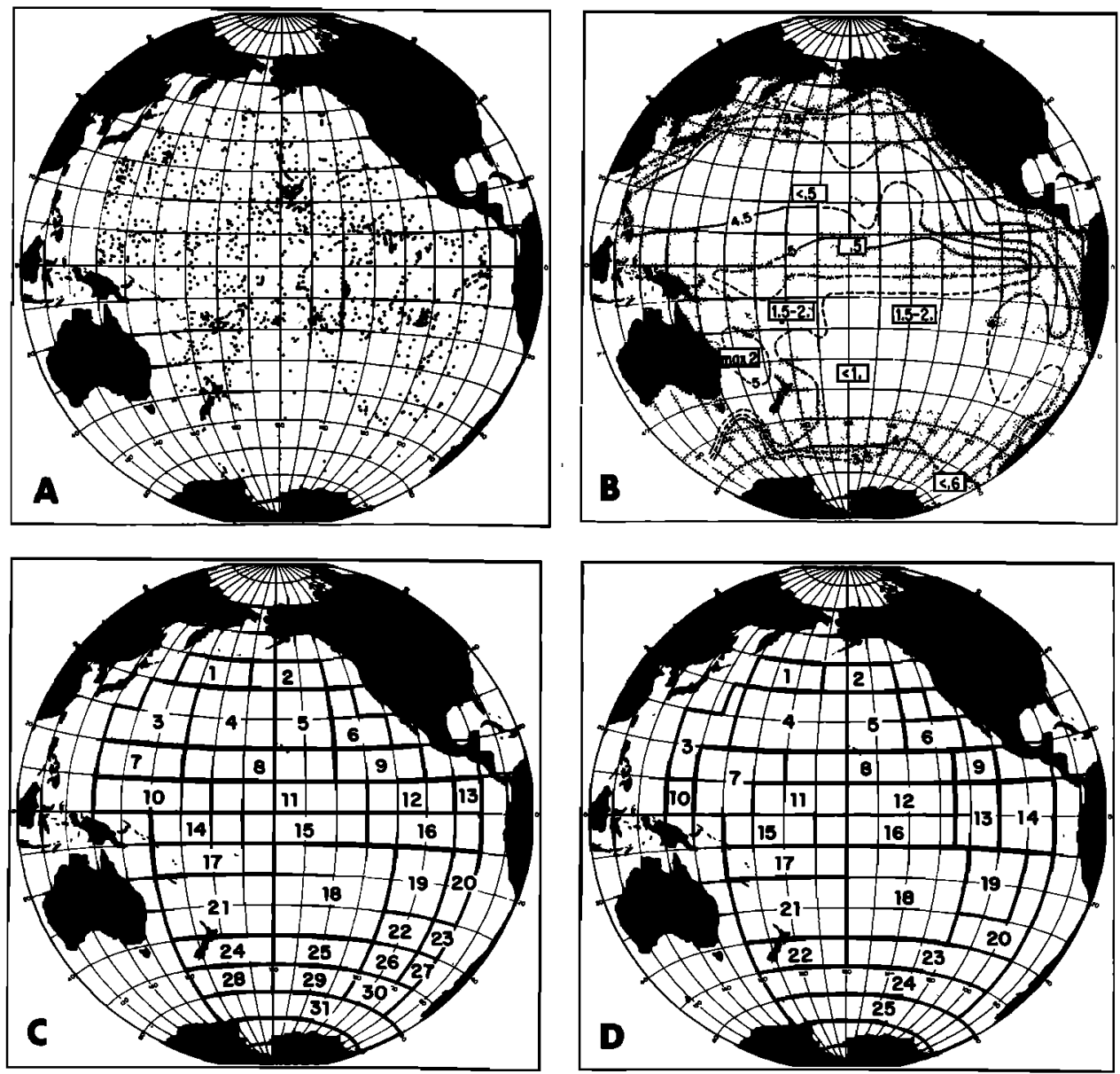

Fig. 3. (a) Locations of data points. Note that samples from ocean margins are not considered. (b) Topography of the calcite compensation depth in kilometers. The boxes indicate aragonite compensation depths (from Berger [1974]). The dot pattern indicates areas of high fertility based upon zooplankton abundances in the upper $150 \mathrm{~m}$ (simplified from Reid [1962] to indicate major patterns of productivity; compare to Koblentz-Mishke et al. [1970]). (c) 'Natural subdivisions' of biogenous sedimentary provinces based on part $b$ and the topography. (d) Final subdivisions, adjusted from part $c$ to minimize scatter in the carbonate versus depth plots (Figures 7-10). All references to areas pertain to this map. 

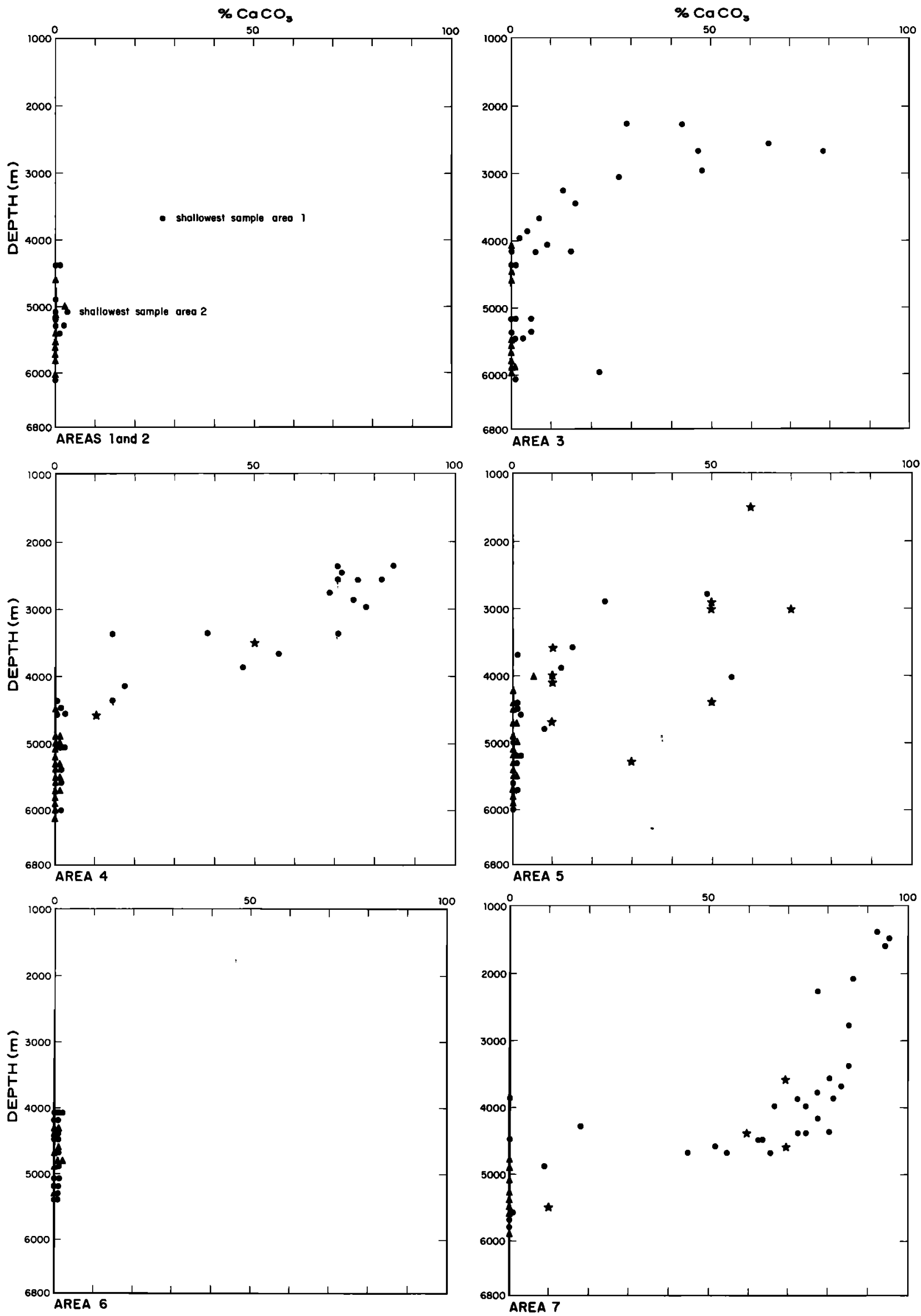

Fig. 4. Plots of carbonate versus depth for areas 1-7 in Figure 3d. The dots represent single samples; the triangles, two or more samples; and the stars, samples for which percentages are given as even multiples of $10 \%$. In many cases these values are estimates. Stars stand for one or more samples. 

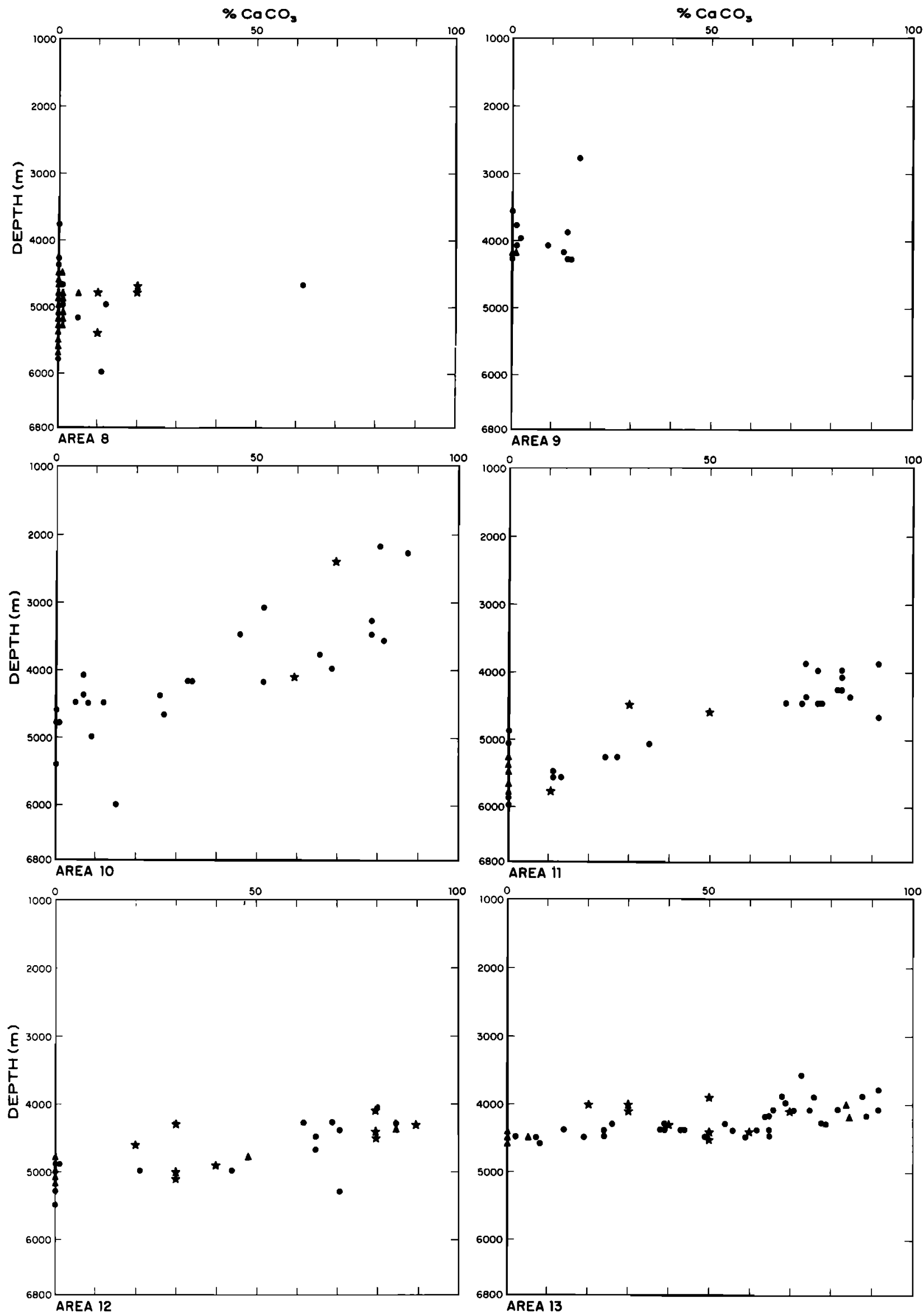

Fig. 5. The same as Figure 4 except plots are for areas 8-13 in Figure $3 d$. 


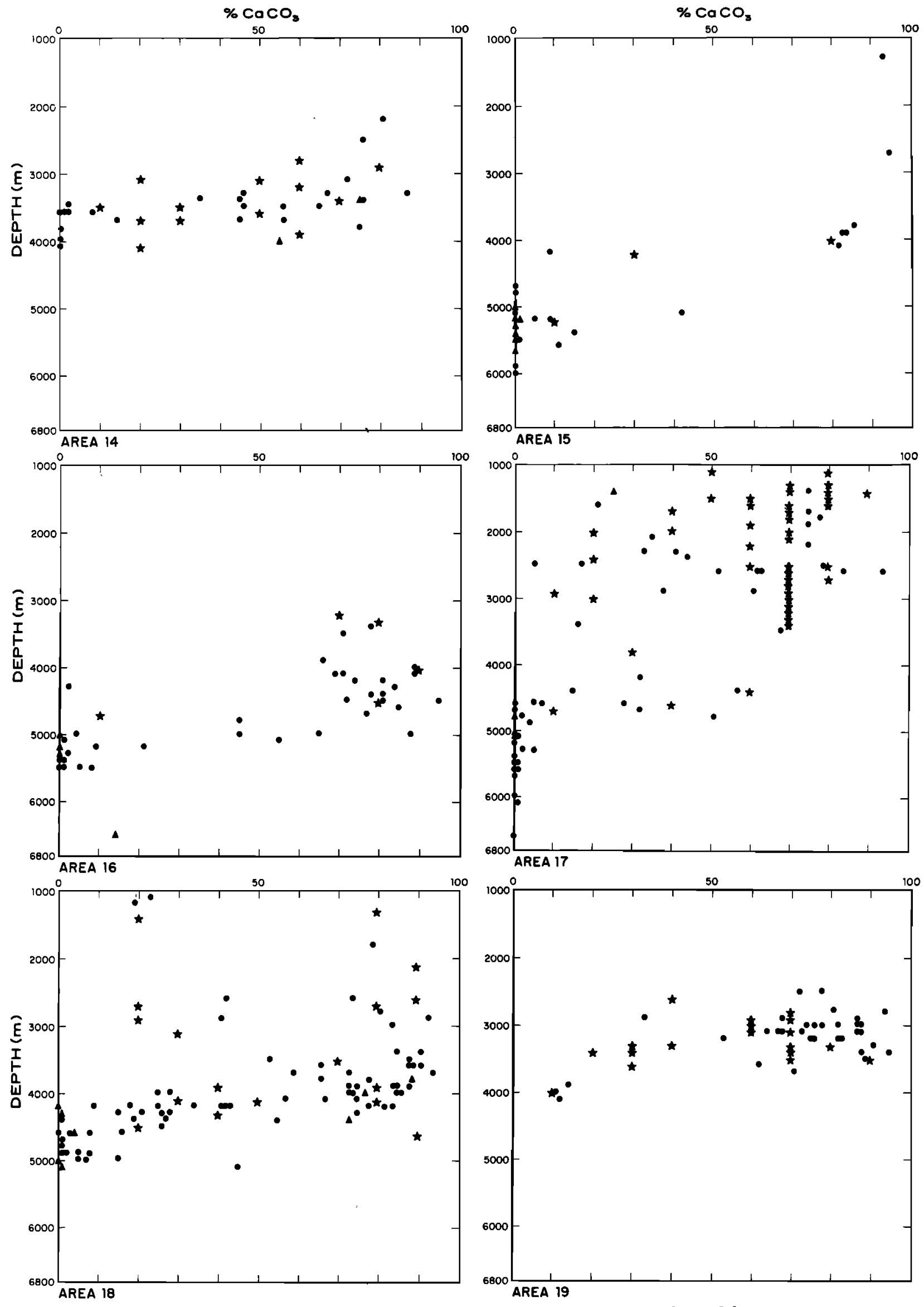

Fig. 6. The same as Figure 4 except plots are for areas 14-19 in Figure 3d. 

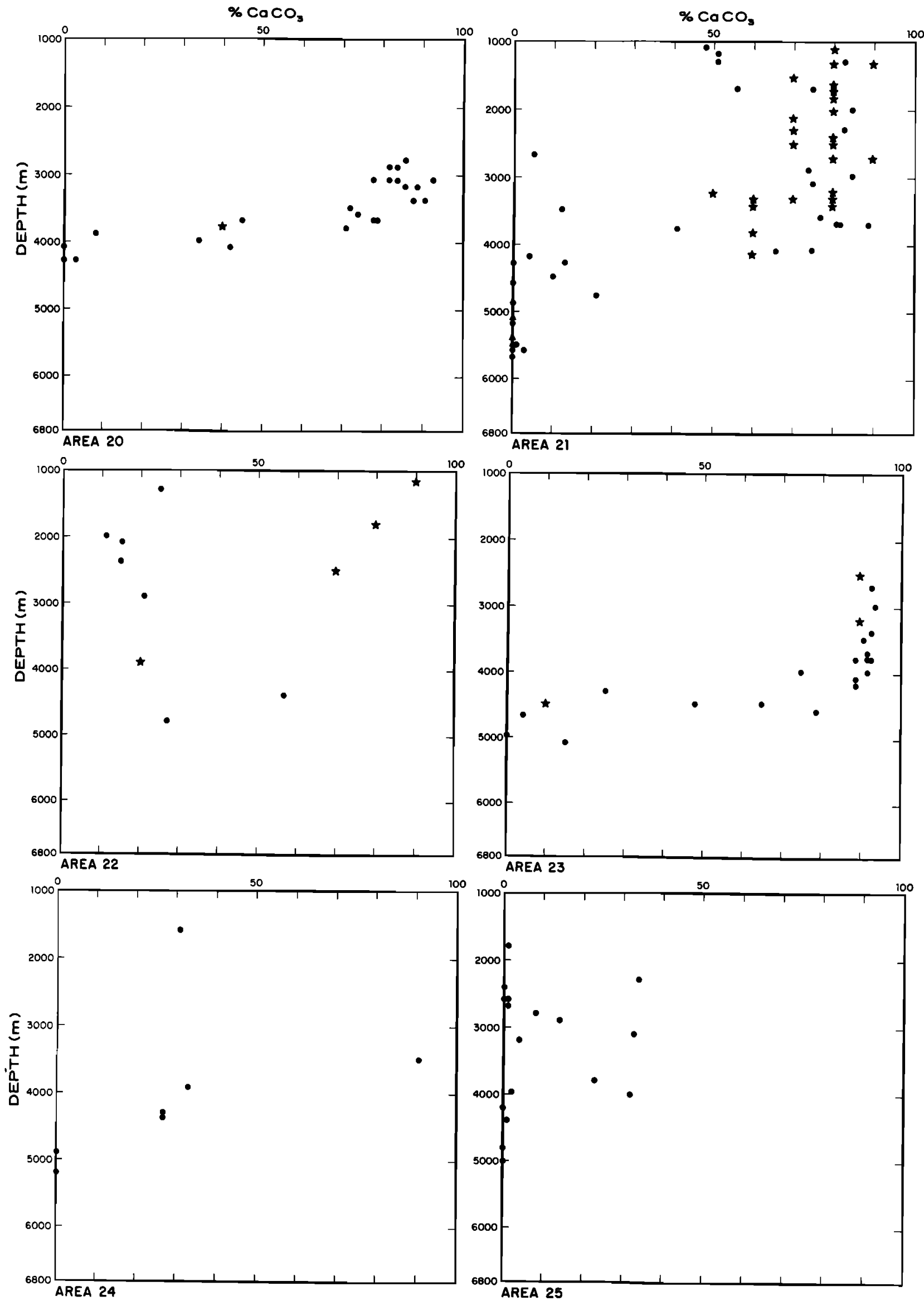

Fig. 7. The same as Figure 4 except plots are for areas 20-25 in Figure 3d. 


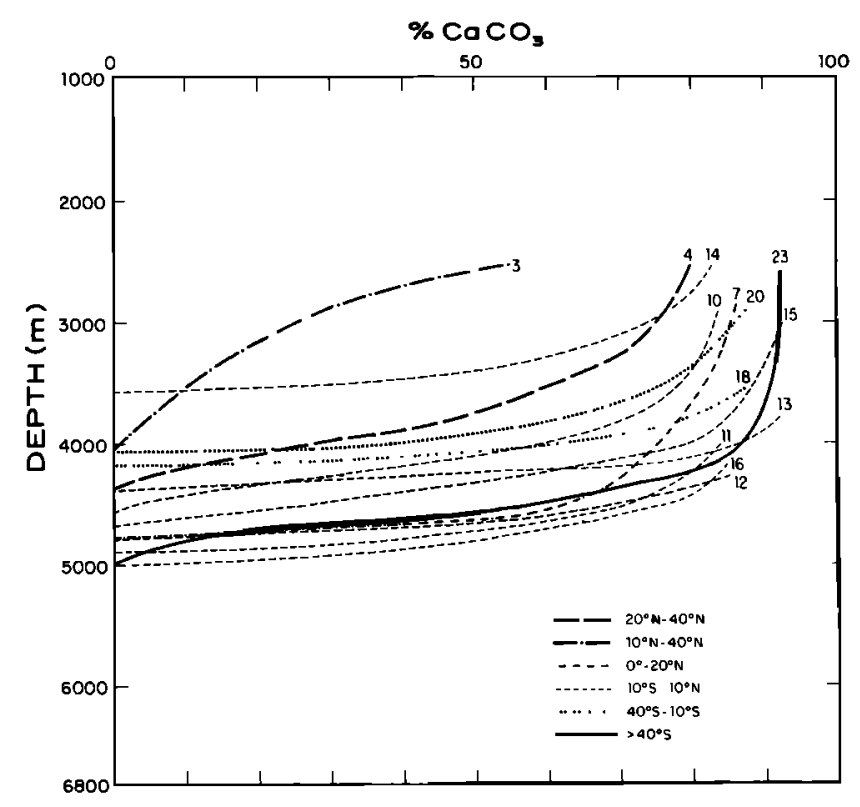

Fig. 8. Generalized carbonate versus depth curves for selected areas.

truncated versions of such ideal ones (e.g., Figure 5, area 13) or else are disturbed by extraneous factors due to high relief (e.g., Figure 6, area 17). or continental influx (e.g., Figure 7, area 25). This assumption enables us to draw some generalized carbonate versus depth curves (in Figure 8, all 'fits' are drawn by hand).

The meaning of such curves in terms of dissolution effects cannot be assessed in the absence of supplementary information. For illustration, in the analysis of the generalized carbonate versus depth curve of area 4 in terms of a dissolution profile (Figure 9), the initial amount of insoluble material $\left(R_{0}\right)$ is critical to the result. If one chooses the three samples near $1500 \mathrm{~m}$ to represent an undissolved and undisturbed condition $\left(R_{0}=6 \%\right)$, the dissolution curve shows a rapid increase from this depth level to $2000 \mathrm{~m}$. After little change from $2000 \mathrm{~m}$ to about $\mathbf{3 5 0 0}$ $\mathrm{m}$, dissolution again rapidly increases until it is complete. If, on the other hand, one assumes that the samples above $2000 \mathrm{~m}$ are not representative of the original supply to greater depths (winnowing can concentrate the coarse carbonate particles), the dissolution curve looks quite different $\left(R_{0}=15 \%\right)$.

The range of depth levels of the carbonate decrease spans more than $1 \mathrm{~km}$, usually between $4-$ and $5-\mathrm{km}$ depth. Interestingly, both remarkably shallow and remarkably deep transitions are seen in the equatorial region, the shallow ones in the east and the deep ones in the central and western parts. The topography of the high to low carbonate transition in the eastern central Pacific appears to be rather complex (Figure 8, areas 12,13, and 14). Both deepwater properties and fertility distributions would seem to be important in the production of these patterns, since both factors influence the chemical environment near the sediment-water interface, which is primarily responsible for the dissolution of the carbonate.

In order to map the CCD, an operational definition has to be agreed upon. Choosing some arbitrary low value, for example, $10 \%$, as an indicator of comparable compensation levels in different regions works well in pelagic areas [Lisitzin, 1970] but appears undesirable elsewhere because of large regional differences in the dilution effect. The one truly comparable value is zero, which is, however, difficult to define in terms of actual measurement. As a criterion for the CCD we have adopted the first occurrence (with increasing depth) of sediment with less than $1 \%$ carbonate and supported at adjoiningly greater depths by other data points with values of less than $3 \%$ calcium carbonate (Figure 10a). Very low percentage values are not very susceptible to dilution effects: as the carbonate content approaches zero, any differences due to dilution approach zero also.

In general, agreement with the CCD contour map (Figure $3 b$ ) is good, which is hardly surprising, since that map is largely based on the same data, although additional foraminiferal data and somewhat more interpretation were used in making the contour map. Where the transition from high carbonate values to noncalcareous sediment is narrow, the definition of the CCD is highly reproducible. Elsewhere there is more room for disagreement. In areas that have low productivity and moderate relief and are distant from the continents the CCD is typically near $4200 \pm 200 \mathrm{~m}$. Presumably, this level largely reflects an increase in dissolution rate (lysocline) at a somewhat shallower depth. In the equatorial zone of high productivity the CCD is depressed to a depth near $4900 \mathrm{~m}$, except in the eastern part, where it shallows.

The depth difference between normal and depressed CCD is a rough indication of the solution rate increase below the lysocline (Figure 11). If we assume that equatorial supply rates of calcite are higher than subtropical ones by a factor of $x$, dissolution rates should increase by the same factor $x$ over the depth difference between normal and depressed CCD, other things being equal. For example, for a supply rate ratio of 4 [Adelseck and Berger, 1975] and for subtropical supply rate of $0.5-1 \mathrm{~cm} / 1000 \mathrm{yr}$, 1.5-3 cm/1000 yr have to be destroyed in the depth inter-

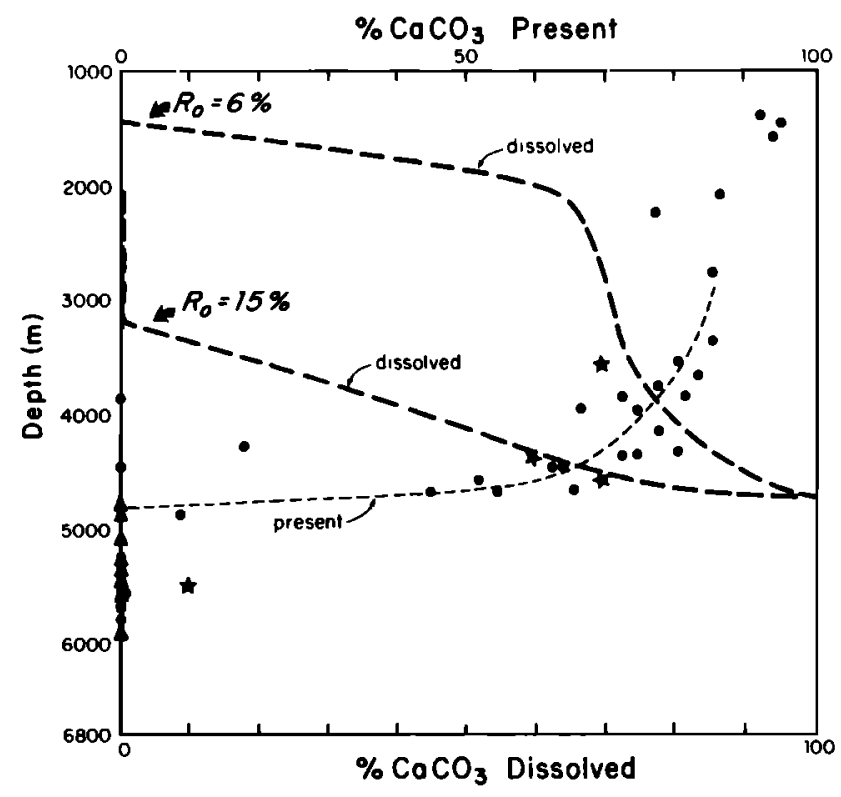

Fig. 9. Two alternative interpretations of a carbonate versus depth plot in terms of dissolution profiles. The thin broken line represents the generalized depth profile of carbonate present in area 7 . The heavy broken lines represent carbonate dissolved, $\boldsymbol{R}_{0}$ $=6 \%$, if the insolubles are assumed to be $6 \%$ of the total sediments, and $R_{0}=15 \%$, if insolubles are $15 \%$. For the basis of assumptions see text. 

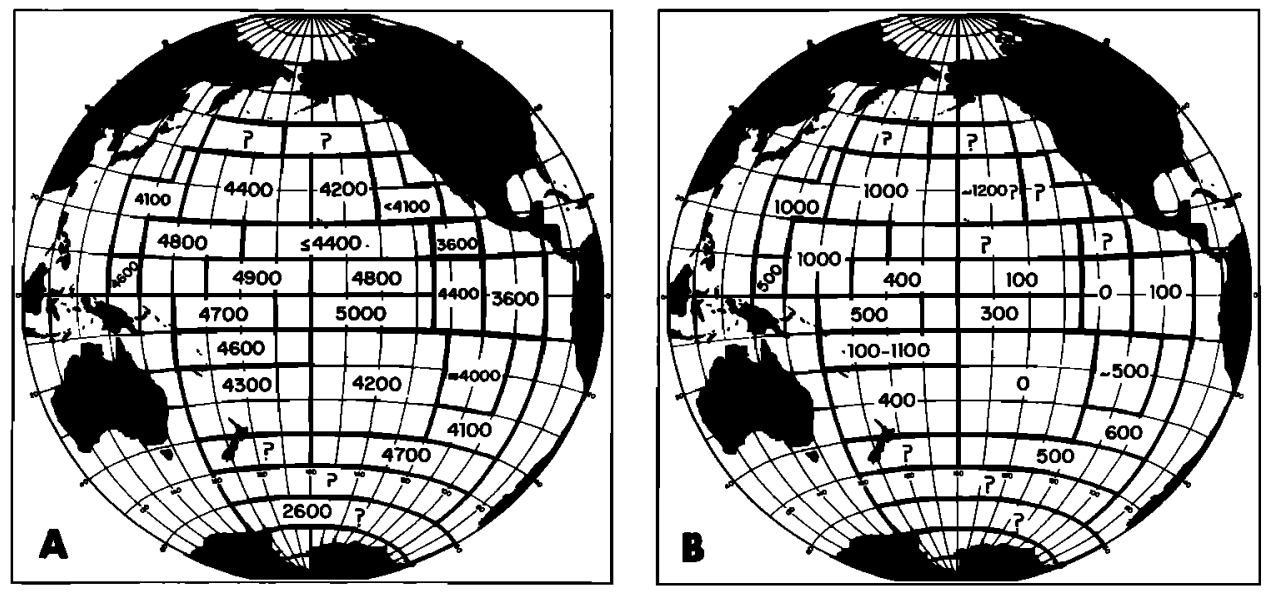

Fig. 10. (a) CCD levels in meters for various areas based on carbonate versus depth plots (Figures 7-10). (b) Thickness of the transition zone in meters between high carbonate values and the CCD. For the operational definitions see text. The question marks are for insufficient data.

val between the subtropical and the equatorial CCD (Figure 11). This would correspond to a dissolution rate gradient of $2.1-4.3 \mathrm{~cm} / 1000 \mathrm{yr} / \mathrm{km}$ depth increase. However, other things are not equal, and additional factors also must be considered. One of these is dissolution during settling, indicated by an inflection in the supply rate at depth (Figure 11). Others are geographic variations in resistance to the skeletal material delivered in carbon dioxide content of interstitial waters and in benthic activity.

The sharpness of the transition from high to low values of carbonate varies for the different regions. To assess this effect, we define a lowermost level of highly calcareous sediment (top of transition) by noting the last occurrence

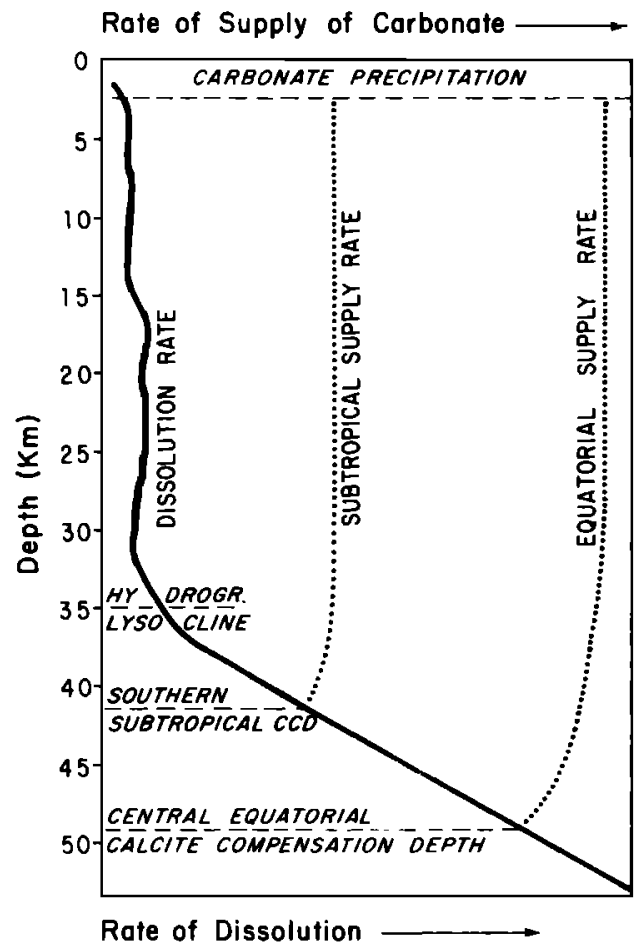

Fig. 11. Simple conceptual model of the equatorial CCD depression. The dissolution rate curve is based on Peterson [1966]. Decrease in supply rate at depth due to dissolution during settling is not quantitative. of high percentages (going down) supported by high values in the adjacent points above. High percentages are those present near depths of $3 \mathrm{~km}$ (or, if not available, greater than 60\%). The base of the transition zone is the CCD, as was defined previously.

The difficulties in devising and applying this kind of definition will be appreciated when attempts are made to check our transition zone values (Figure 10b) with the original scatter plots (Figures 4-7). Nevertheless, trends can be recognized. The transition from high to low carbonate values takes place within a few hundred meters in the equatorial regions and in the South Pacific but takes up some $1000 \mathrm{~m}$ in the North Pacific. Several factors may be responsible for this striking difference. The initial percentage of carbonate seems to have relatively little effect on the thickness of the transition zone (Figure 12a). It appears to be necessary to postulate that dissolution of carbonate at relatively shallow depths is much greater in the North Pacific than elsewhere but that dissolution rates at

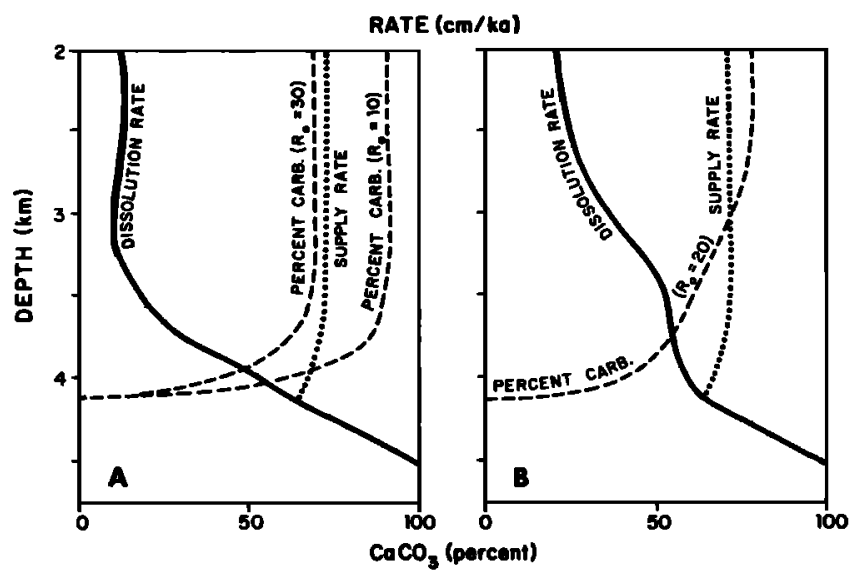

Fig. 12. Two models illustrating the concept of 'thickness of transition' in a carbonate versus depth plot. The solid lines indicate dissolution rate profiles; the dotted lines, supply rate profiles; and the broken lines, carbonate versus depth curves resulting from the (assumed) rate profiles for various values of $R_{0}$ (insoluble fraction). (a) The dissolution rate profile of Peterson [1966], narrow transition zone. (b) The hypothetical two-stage dissolution rate increase, necessary and sufficient for a considerable widening of the transition zone if supply and dissolution are the only controlling factors. 
great depths remain comparable (Figure 12b). This suggestion is supported by the topography of the aragonite compensation depth (Figure $3 b$ ). An important difficulty in this type of interpretation is well illustrated in area 13 of Figure 5, whose plot suggests a very sharp transition. In fact, the scatter merely indicates that carbonate values of a wide range coexist in a narrow depth band. This could be due to a strong depth gradient, or equally likely to a strong latitudinal gradient, in combination with redeposition and pre-Recent outcrops. There is some doubt therefore that depth averages of scatter plots in the equatorial zone [Bramlette, 1961; Heath and Culberson, 1970] can be interpreted in a straightforward fashion.

In conclusion, the time-honored practice of plotting carbonate percentages versus depth leads to some useful general concepts such as the geographic variability of the CCD and the variation in the sharpness of the CCD transition. Such mapping opens the way for asking pertinent questions about the processes of supply, dilution, dissolution, and redeposition, which control the distributions. However, to answer these questions, it is necessary to map the rates of accumulation as well as the states of preservation of the calcareous components.

Acknowledgments. Research was supported by the Oceanogra. phy Section of the National Science Foundation grant GA-41078 and by the Office of Naval Research grant $N$ 00014-69-A0200-6049. We are grateful to P. E. Biscaye for critical review of this paper. Jane Z. Frazer of SIO aided in retrieving information from 1313 data points.

\section{REFERENCES}

Adelseck, C. G., and W. H. Berger, On the dissolution of planktonic foraminifera and associated microfossils during settling and on the sea floor, Spec. Publ. 13, pp. 70-81, Cushman Found. for Foraminiferal Res., Washington, D. C., 1975.

Arrhenius, G., Sediment cores from the east Pacific, Rep. Swed. Deep Sea Exped. 1947-1948, 5, 1-228, 1952.

Belyaeva, N. V., Quantitative distribution of planktonic foraminiferal tests in Recent sediments of the Pacific Ocean (in Russian, English abstract), Okeanologiya, 8(1), 111-115, 1968.

Belyaeva, N. V., The distribution of planktonic foraminifera in the water and sediment of the Antarctic Ocean (in Russian), Okeanologiya, 9(6), 1063-1069, 1969.

Belyaeva, N. V., and Kh. M. Saidova, Relations between the benthic and planktonic foraminifera in the uppermost layers of Pacific sediments, Okeanologiya, 5(6), 1010-1014, 1965. (Oceanology, Engl. Transl., 5(6), 56-59, 1965.)

Ben-Yaakov, S., and I. R. Kaplan, Deep-sea in situ calcium carbonate saturometry, J. Geophys. Res., 76, 722-731, 1971.

Ben-Yaakov, S., E. Ruth, and I. R. Kaplan, Carbonate compensation depth: Relation to carbonate solubility in ocean waters, Science, 184, 982-984, 1974.

Berger, W. H., Foraminiferal ooze: Solution at depth, Science, 156, 383-385, 1967.

Berger, W. H., Planktonic foraminifera: Selective solution and the lysocline, Mar. Geol., 8, 111-138, $1970 a$.

Berger, W. H., Biogenous deep-sea sediments: Fractionation by deep-sea circulation, Geol. Soc. Amer. Bull., 81, 1385-1402, $1970 b$.

Berger, W. H., Sedimentation of planktonic foraminifera, Mar. Geol., 11, 325-358, 1971.

Berger, W. H., Cenozoic sedimentation in the eastern tropical Pacific, Geol. Soc. Amer. Bull., 84, 1941-1954, $1973 a$.

Berger, W. H., Deep-sea carbonates: Pleistocene dissolution cycles, J. Foraminiferal Res., 3(4), 187-195, $1973 b$.

Berger, W. H., Deep-sea sedimentation, in The Geology of Continental Margins, edited by C. A. Burk and C. L. Drake, pp. 213-241, Springer, New York, 1974.
Berger, W. H., Sedimentation of deep-sea carbonates: Maps and models of variations and fluctuations, in Marine Plankton and Sediments, edited by W. R. Riedel and T. Saito, Micropaleontology Press, New York, in press, 1976.

Berger, W. H., and E. L. Winterer, Plate stratigraphy and the fluctuating carbonate line, Pelagic Sediments on Land and Under the Sea, edited by K. J. Hsit and H. C. Jenkyns, Spec. Publ. 1, pp. 59-96, Int. Ass. of Sedimentol., Oxford, England, 1974.

Berner, R. A., Physical chemistry of carbonates in the oceans, Studies in Paleo-oceanography, Soc. Econ. Paleontol. Mineral. Spec. Publ. 20, 37-43, 1974.

Berner, R. A., and P. Wilde, Dissolution kinetics of $\mathrm{CaCO}_{3}$ in seawater, 1, Saturation state parameter for kinetic calculations, Amer. J. Sci., 272, 826-839, 1972.

Bezrukov, P. L. (Ed.), Microflora and microfauna in the Recent sediments of the Pacific Ocean, The Pacific Ocean, Akad. Nauk SSSR Moscow, 8, 1-201, 1969.

Blackman, A., Pleistocene stratigraphy of cores from the southeast Pacific Ocean, Ph.D. thesis, 200 pp., Univ. of Calif., San Diego, 1966.

Blair, D. G., The distribution of planktonic foraminifera in deepsea cores from the Southern Ocean, Antarctica, contribution 10, 141 pp., Dep. of Geol., Fla. State Univ., Tallahassee, 1965.

Bramlette, M. N., Pelagic sediments, Oceanography, edited by $\mathbf{M}$. Sears, Publ. 67, pp. 345-366, Amer. Ass. for the Advan. of Sci., Washington, D. C., 1961.

Broecker, W. S., Calcite accumulation rates and glacial to interglacial changes in oceanic mixing, in The Late Cenozoic Glacial Ages, edited by K. K. Turekian, pp. 239-265, Yale University Press, New Haven, Conn., 1971.

Broecker, W. S., Chemical Oceanography, 214 pp., Harcourt, Brace, and Jovanovich, New York, 1974.

Broecker, W. S., and S. Broecker, Carbonate dissolution on the western flank of the East Pacific Rise, Studies in Paleooceanography, Soc. Econ. Paleontol. Mineral. Spec. Publ. 20, 44-57, 1974.

Chave, K. E., and S. V. Smith, Inorganic cycles of calcium and carbon in the oceans, in Biogeochemistry, edited by $\mathrm{E}$. Ingerson, Clarke, Washington, D. C., 1973.

Chave, K. E., and E. Suess, Calcium carbonate saturation in seawater: Effects of dissolved organic matter, Limnol. Oceanogr., 15, 633-637, 1970.

Echols, R. J., and J. P. Kennett, Distribution of foraminifera in the surface sediments, Antarctic Map Folio Ser., folio 17, pp. 13-17, Amer. Geogr. Soc., New York, 1973.

Edmond, J. M., On the dissolution of carbonate and silica in the deep ocean, Deep Sea Res., 21, 455-480, 1974.

Funnell, B., Oceanic micropaleontology of the South Pacific, in Scientific Exploration of the South Pacific, pp. 133-151, National Academy of Sciences, Washington, D. C., 1970.

Funnell, B. M., The occurrence of pre-Quaternary microfossils in the oceans, in The Micropaleontology of Oceans, pp. 507-534, edited by B. M. Funnell and W. R. Riedel, Cambridge University Press, New York, 1971.

Gieskes, J. M., The alkalinity-total carbon dioxide system in seawater, in The Sea, edited by E. D. Goldberg, pp. 5, 123-151, Interscience, New York, 1974.

Hays, J. D., T. Saito, N. D. Opdyke, and L. H. Burckle, PliocenePleistocene sediments of the equatorial Pacific: Their paleomagnetic, biostratigraphic, and climatic record, Geol. Soc. Amer. Bull., 80, 1481-1514, 1969.

Heath, G. R., Carbonate sedimentation in the abyssal equatorial Pacific during the past 50 million years, Geol. Soc. Amer. Bull., 80, 689-694, 1969 .

Heath, G. R., and C. Culberson, Calcite: Degree of saturation, rate of dissolution, and the compensation depth in the deep oceans, Geol. Soc. Amer. Bull., 81, 3157-3160, 1970.

Herb, R., Recent planktonic foraminifera from sediments of the Drake Passage, Southern Ocean, Eclogae Geol. Helv., 61(2), 467-480, 1968.

Herb, R., Distribution of Recent benthonic foraminifera in the Drake Passage, in Biology of the Antarctic Seas 4, Antarctic Res. Ser., vol. 17, pp. 251-300, AGU, Washington, D. C., 1971.

Hoshino, M., and R. Higano, Calcium carbonate contents in deepsea sediments in equatorial region, J. Oceanogr. Soc. Jap., 17, $1-7,1961$.

Kennett, J. P., Foraminiferal evidence of a shallow calcium car- 
bonate solution boundary, Ross Sea, Antarctica, Science, 153(3732), 191-193, 1966.

Kennett, J. P., Distribution of planktonic foraminifera in surface sediments southeast of New Zealand, Proc. 1st Int. Conf. Planktonic Microfossils Geneva, 2, 307-322, 1969.

Koblentz-Mishke, O. J., V. V. Volkovinsky, and J. G. Kabanova, Plankton primary production of the world ocean, in Scientific Exploration of the South Pacific, edited by W. S. Wooster, pp. 183-193, National Academy of Sciences, Washington, D. C., 1970.

Li, Y. H., T. Takahashi, and W. S. Broecker, Degree of saturation of $\mathrm{CaCO}_{3}$ in the oceans, J. Geophys. Res., 74, 5507-5525, 1969.

Lisitzin, A. P., Sedimentation and geochemical considerations, in Scientific Exploration of the South Pacific, edited by W. S. Wooster, pp. 89-132, National Academy of Sciences, Washington, D. C., 1970.

Lisitzin, A. P., Distribution of carbonate microfossils in suspension and in bottom sediments, in The Micropaleontology of Oceans, edited by B. M. Funnell and W. R. Riedel, pp. 197-218, Cambridge University Press, New York, 1971.

Lisitzin, A. P., Sedimentation in the world ocean, Soc. Econ. Paleontol. Mineral. Spec. Publ. 17, 218, 1972.

Lisitzin, A. P., Osadkoobrazovanie v Okeanakh, p. 438, Izdatelstvo Nauka, Moscow, 1974.

Lisitzin, A. P., and V. P. Petelin, Features of distribution and modification of $\mathrm{CaCO}_{3}$ in bottom sediments of the Pacific Ocean, Lithol. Mineral Resour., 5, 565-578, 1967.

Lyakhin, Yu. I., Calcium carbonate saturation of Pacific water, Okeanologiya, 8(1), 56-68, 1968. (Oceanology, Engl. Transl., $8(1), 44-63,1968$.

Menard, H. W., Marine Geology of the Pacific, pp. 11-23, McGrawHill, New York, 1964.

Moore, T. C., G. R. Heath, and R. O. Kowsman, Biogenic sediments of the Panama Basin, J. Geol., 81, 458-472, 1973.

Morse, J. W., and R. A. Berner, Dissolution kinetics of calcium carbonate in seawater, 2, A kinetic origin for the lysocline, Amer. J. Sci., 272, 840-851, 1972.

Murray, J., and A. F. Renard, Report on deep-sea deposits based on the specimens collected during the voyage of $H . M . S$. Challenger in the years 1872 to 1876 , in Report of the Voyage Challenger, 525 pp., Longmans, London, 1891.

Olausson, E., Sediment cores from the West Pacific, Rep. Swed. Deep Sea Exped. 1947-1948, 6(5), 161-214, 1960.

Olausson, E., Evidence of climatic changes in North Atlantic deep-sea cores, with remarks on isotopic paleotemperature analysis, Progr. Oceanogr., 3, 221-252, 1965.

Olausson, E., Climatological, geoeconomical and paleooceanographical aspects on carbonate disposition, Progr. Oceanogr., 4, 245-265, 1967.

Olausson, E., Quaternary correlations and the geochemistry of oozes, in The Micropaleontology of Oceans, edited by B. M. Funnell and W. R. Riedel, pp. 375-398, Cambridge University Press, New York, 1971.

Parker, F. L., and W. H. Berger, Faunal and solution patterns of planktonic foraminifera in surface sediments of the South Pacific, Deep Sea Res., 18, 73-107, 1971.

Peterson, M. N. A., Calcite: Rates of dissolution in a vertical profile in the central Pacific, Science, 154(3756), 1542-1544, 1966.

Pytkowicz, R. M., The carbon dioxide-carbonate system at high pressures in the oceans, Oceanogr. Mar. Biol. Ann. Rev., 6, 83-135, 1968.

Pytkowicz, R. M., On the carbonate compensation depth in the Pacific Ocean, Geochim. Cosmochim. Acta, 34, 836-839, 1970.

Reid, J. L., On circulation, phosphate-phosphorus content, and zooplankton volumes in the upper part of the Pacific Ocean, Limnol. Oceanogr., 7, 287-306, 1962.

Revelle, R. R., Marine bottom samples collected in the Pacific Ocean by the Carnegie on its seventh cruise, 1, Publ. 556, 180 pp., Carnegie Inst., Washington, D. C., 1944.

Revelle, R. R., and R. Fairbridge, Carbonates and carbon dioxide, Geol. Soc. Amer. Mem., 67, 239-296, 1957.

Riedel, W. R., and B. M. Funnell, Tertiary sediment cores and microfossils from the Pacific Ocean floor, Quart. J. Geol. Soc. London, 120, 305-368, 1964.

Roth, P. H., and W. H. Berger, Distribution and dissolution of coccoliths in the South and Central Pacific, Spec. Publ. 13, Cushman Found. for Foraminiferal Res., Washington, D. C., 1975.

Saidova, Kh. M., Distribution of benthic foraminifera in the Pacific, Oceanology, 5, 72-83, 1965.

Saidova, Kh. M., On foraminifera distribution near the Pacific coast of South America (in Russian, English abstract), Okeanologiya, 11(2), 256-265, 1971.

Saito, T., L. H. Burckle, and J. D. Hays, Implications of some preQuaternary sediment cores and dredgings, Studies in Paleooceanography, Soc. Econ. Paleontol. Mineral. Spec. Publ. 20, 6-36, 1974.

Sliter, W. V., A. W. H. Bé, and W. H. Berger (Eds.), Dissolution of deep-sea carbonates, Spec. Publ. 13, p. 159, Cushman Found. for Foraminiferal Res., Washington, D. C., 1975.

Smith, S. V., J. A. Dygas, and K. E. Chave, Distribution of calcium carbonate in pelagic sediment, Mar. Geol., 6, 391-400, 1968.

Takahashi, T., Carbonate chemistry of seawater and the calcium carbonate compensation depth in the oceans, Spec. Publ. 13, pp. 11-261, Cushman Found. for Foraminiferal Res., Washington, D. C., 1975

Takahashi, T., R. F. Weiss, C. H. Culberson, J. M. Edmond, D. E. Hammond, C. S. Wong, Y. H. Li, and A. E. Bainbridge, A carbonate chemistry profile at the 1969 Geosecs intercalibration station in the eastern Pacific Ocean, J. Geophys. Res., 75(36), 7648-7666, 1970.

Theyer, F., Benthic foraminifera: Bathymetric patterns of calcareous and arenaceous assemblages, Nature Phys. Sci., 229(7), 207-209, 1971 a.

Theyer, F., Benthic foraminiferal trends, Pacific-Antarctic Basin, Deep Sea Res., 18, 723-738, $1971 b$.

Tin, M. T., A. D. Suttle, and W. M. Sackett, Uranium concentrations in marine sediments, Geochim. Cosmochim. Acta, 37, 35-51, 1973.

Valencia, M. J., Calcium carbonate and gross-size analysis of surface sediments, western equational Pacific, Pac. Sci., 27(3), 290-303, 1973.

van Andel, Tj. H., G. R. Heath, and T. C. Moore, Conozoic tectonics, sedimentation and paleo-oceanography of the central equatorial Pacific, Geol. Soc. Amer. Mem. 85, 134 pp., 1975.

(Received January 20, 1975;

revised June 12,1975 ;

accepted June 12, 1975.) 